EXTENDED REPORT

\title{
Low circulating soluble interleukin 2 receptor level predicts rapid response in patients with refractory rheumatoid arthritis treated with infliximab
}

\author{
A Kuuliala, R Nissinen, H Kautiainen, H Repo, M Leirisalo-Repo
}

See end of article for authors' affiliations

Correspondence to:

Antti Kuuliala, Haartman

Institute, Department of

Bacteriology and

Immunology, PO Box 21

(Haartmaninkatu 3), FIN-

00014 Helsingin Yliopisto,

Helsinki, Finland; antti.

kuuliala@helsinki.fi

Accepted 2 June 2005

Published Online First

7 June 2005

Ann Rheum Dis 2006;65:26-29. doi: 10.1136/ard.2004.034728

Background: Treatment with infliximab induces a rapid therapeutic response in most patients with active rheumatoid arthritis. Factors predicting good response are not well known.

Objective: To study the predictive value of baseline level of soluble interleukin 2 receptor (sIL2R), a marker of lymphocyte activation, on the treatment response.

Methods: 24 patients with active rheumatoid arthritis received intravenous infusions of infliximab at study entry, at two weeks, at six weeks, and at eight week intervals thereafter. Outcome was evaluated at six weeks and 22 weeks. Clinical assessment and standard laboratory tests were made and the DAS28 disease activity score was calculated. Serum sIL2R level at entry was measured by automated immunoassay analyser (Immulite ${ }^{\circledR}$ ). The mean change in DAS28 score from entry to six weeks and 22 weeks was calculated and related to sIL2R level using baseline adjusted robust regression analysis.

Results: Baseline level of serum sIL2R (mean (SD), 621 (325) U/ml) did not correlate with baseline DAS28 score $(r=0.24$ (95\% confidence interval, -0.18 to 0.58$)$ ). At six weeks DAS28 scores improved, with a mean change of $-2.53(-3.08$ to -1.98$)(p<0.001)$. This change was predicted by low baseline sIL2R level (regression coefficient per $100 \mathrm{U} / \mathrm{ml}: 0.205(0.003$ to 0.407$)(p=0.047))$. At 22 weeks the DAS28 scores improved, with a mean change of $-2.26(-2.75$ to -1.77$)(p<0.001)$. The change was not predicted by baseline sIL2R level.

Conclusions: Low baseline sIL2R level may predict a rapid clinical response in patients with refractory rheumatoid arthritis treated with infliximab.

$\mathrm{R}$ heumatoid arthritis is a systemic autoimmune disease characterised by polyarticular joint inflammation. The disease is heterogeneous with respect to clinical features, genetic background, and immunopathogenesis. The pathogenesis of rheumatoid arthritis is incompletely understood. It involves collaboration between dendritic cells, $\mathrm{T}$ cells, and monocytes/macrophages, which may initiate and perpetuate immune activation. ${ }^{12}$ Activated CD4+ T cells in the synovium stimulate monocytes and macrophages which produce proinflammatory cytokines, causing synovial inflammation. The synovium can have features of lymphocytic follicles. ${ }^{3}$ Indeed, T cells are the most abundant cells in the pannus.

Upon activation, $\mathrm{T}$ cells express on their surface interleukin 2 receptor (IL2R) which is shed from the cells and can be detected as a soluble form of IL2R (sIL2R) in synovial fluid and in serum. Activation of T lymphocytes can be evaluated by measuring circulating levels of sIL2R. ${ }^{4}$

A key proinflammatory cytokine in rheumatoid inflammation is tumour necrosis factor (TNF). Monocytes and macrophages are the major source of TNF. ${ }^{1}$ The blockade of TNF with infliximab, a chimeric monoclonal anti-TNF antibody, results in a rapid clinical response in the majority of rheumatoid patients. However, only $20-40 \%$ of the patients achieve a good clinical response ( $\geqslant$ ACR50). In the rest of the patients, the effect is only modest or is not observed at all. ${ }^{5}$ The reasons for varying responses are largely unknown, but inflammatory and immunological heterogeneity of patients with rheumatoid arthritis might be one explanation.

We have recently presented data suggesting that low baseline serum sIL2R levels may predict early remission in patients with early active DMARD-naive rheumatoid arthritis treated with a single DMARD. ${ }^{6}$ This prompted us to study whether baseline sIL2R level serves as a predictor of early treatment response to treatment with infliximab in rheumatoid patients refractory to conventional DMARDs. We reasoned that strong lymphocyte activation, as defined by high levels of sIL2R in the circulation, may, by intensifying macrophage TNF production, delay the clinical response to, or even render the patient refractory to, treatment with infliximab. Here we report that low circulating sIL2R level may predict rapid response to infliximab treatment.

\section{METHODS}

This study comprises 24 patients with chronic active rheumatoid arthritis. Treatment with all conventional DMARDs had failed. Nineteen patients $(79 \%)$ were on low dose prednisolone ( $\leqslant 15 \mathrm{mg} /$ day). After starting infliximab, DMARD treatment was continued with minor modifications during the study period.

All patients gave their informed consent for participation in the study. The study protocol was approved by the ethics committee of the Helsinki University Central Hospital.

The patients received infliximab infusions $(3-4 \mathrm{mg} / \mathrm{kg})$ at entry, and at two weeks, six weeks, 14 weeks, and 22 weeks. The outcome was assessed at six weeks and 22 weeks (one patient died before the 22 week check up visit). Swollen and tender joints were counted. Patient's assessment of pain, and patient's and physician's global assessments were recorded on a $10 \mathrm{~cm}$ visual analogue scale. The patients filled in the Finnish version of the Stanford Health Assessment Questionnaire (HAQ) ${ }^{7}$ and the HAQ score was calculated.

Abbreviations: DAS28, 28 joint disease activity score; DMARD, disease modifying antirheumatic drug; $\mathrm{HAQ}$, Health Assessment Questionnaire; sIL2R, soluble interleukin 2 receptor 


\begin{tabular}{ll} 
Table 1 & \multicolumn{1}{c}{ Baseline characteristics of the patients } \\
\hline Age (years) (mean (range)) & $54.8(34$ to 76$)$ \\
Disease duration (years) (median (range)) & $14(3$ to 32) \\
Sex, female (n (\%)) & $18(75 \%)$ \\
Rheumatoid factor seropositive (n (\%)) & $11(58 \%)$ \\
\hline
\end{tabular}

Erythrocyte sedimentation rate (ESR) and serum $\mathrm{C}$ reactive protein concentrations were measured using standard laboratory methods. The DAS28 disease activity score was calculated. ${ }^{8}$ Immediately before the first infliximab infusion, blood was collected into EDTA, and plasma was separated by centrifugation and frozen at $-20^{\circ} \mathrm{C}$. The sIL2R levels were measured by Immulite ${ }^{\circledR}$ automated immunoassay analyser (DPC, Los Angeles, California, USA). The sIL2R measurements were carried out blinded, without knowledge of the clinical data.

Pearson correlation coefficients were calculated for serum sIL2R level and baseline DAS28 score. The changes in DAS28 scores, with $95 \%$ confidence intervals (CI) were calculated. Probability (p) values for changes in DAS28 scores were calculated by the $t$ test. The predictive value of baseline sIL2R level for change in DAS28 score at six and 22 weeks was calculated by robust regression analysis. This type of regression analysis, in which the weight given to outliers is reduced, is appropriate for analysis of small datasets because it makes the results less sensitive to the presence of outliers.

\section{RESULTS}

Table 1 presents the characteristics of the patients and table 2 the DMARDs used by the patients. The mean (SD) serum sIL2R was 621 (325) U/ml, and the DAS28 score, 6.3 (1.0). The serum sIL2R level did not correlate with the baseline DAS28 score ( $r=0.24$ (95\% CI, -0.18 to 0.58$)$ ).

There was a distinct clinical response to infliximab. At six weeks, DAS28 scores improved (mean (SD) score, 3.7 (1.7)), with a mean change of $-2.53(95 \% \mathrm{CI},-3.08$ to -1.95$)$ $(p<0.001)$. This change was predicted by baseline sIL2R level (table 3; fig 1A) but not by baseline DAS28 score or infliximab dose. At 22 weeks, the mean DAS28 score was $4.0(1.2))$, and the mean change from baseline was -2.26 $(-2.75$ to -1.77$)(\mathrm{p}<0.001)$. This change was predicted by neither the baseline sIL2R level (table 3; fig 1B) nor the baseline DAS28 score or infliximab dose.

In four patients initially receiving a combination of DMARDs the treatment regimen was tapered as their clinical
Table 2 Disease modifying antirheumatic drugs used by the patients at entry

\begin{tabular}{ll}
\hline Treatment & $\mathbf{n}(\%)$ \\
\hline Single therapy & $15(62)$ \\
Methotrexate & $7(29)$ \\
Leflunomide & $6(25)$ \\
Azathioprine & $1(4)$ \\
Podophyllotoxine & $1(4)$ \\
Combination therapy & $9(38)$ \\
Methotrexate + leflunomide & $1(4)$ \\
Methotrexate + podophyllotoxine & $1(4)$ \\
Methotrexate + hydroxychloroquine + podophyllotoxine & $2(8)$ \\
Methotrexate + hydroxychloroquine + sulfasalazine & $1(4)$ \\
+ciclosporine A & $1(4)$ \\
Azathioprine + gold sodium thiomalate & $1(4)$ \\
Azathioprine + sulfasalazine & $1(4)$ \\
Podophyllotoxine + hydroxychloroquine & $1(4)$ \\
Hydroxychloroquine + auranofin & \\
\hline
\end{tabular}

condition improved during the infliximab treatment. One patient had a temporary pause in the methotrexate treatment because of raised liver enzyme levels.

\section{DISCUSSION}

The results show that low serum sIL2R level predicts early (six weeks) response to infliximab treatment. To the best of our knowledge such a predictor for early response has not been described before. Given that the serum sIL2R level serves as a marker to T cell activation, ${ }^{4}$ our results suggest that enhanced $\mathrm{T}$ cell activation is related to delayed response to the infliximab treatment. This suggestion emphasises the impact of lymphocytes on the rheumatic inflammation and is supported by at least two lines of evidence.

First, about one third of patients with rheumatoid arthritis have extensive lymphocytic infiltration in the synovium with $\mathrm{T}$ and $\mathrm{B}$ cell conglomerates, sometimes forming germinal centres. Such patients have a more active disease and higher levels of sIL2R in their sera. ${ }^{10}$ Consequently, the patients with high baseline sIL2R may have large numbers of activated $\mathrm{T}$ cells in the synovium, thus requiring several infliximab infusions before the synovial infiltrate is reduced and disease activity is lowered.

Second, we have previously investigated chemokine receptor expression on circulating lymphocytes in the same patients. The patients responding to infliximab (fulfilling the ACR20 response) had smaller numbers of T cells expressing
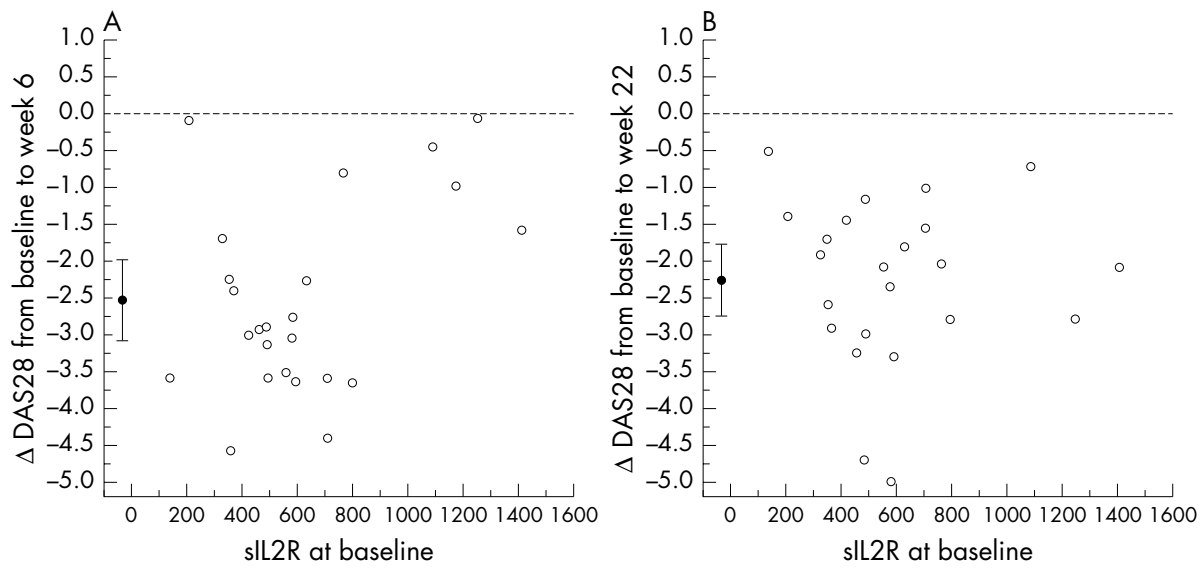

Figure 1 Baseline serum soluble interleukin 2 receptor (sIL2R) versus change in 28 joint disease activity score ( $\triangle D A S 28)$ from baseline to six weeks and baseline to 22 weeks. The filled circles represent the means (with $95 \%$ confidence intervals). 
Table 3 Baseline adjusted robust regression for baseline serum soluble interleukin 2 receptor (sIL2R) predicting change in 28 joint disease activity score (DAS28) after six and 22 weeks

\begin{tabular}{|c|c|c|c|c|}
\hline \multirow[b]{3}{*}{ Explanatory variable } & \multicolumn{4}{|l|}{ DAS28 change from baseline } \\
\hline & \multicolumn{2}{|l|}{ After 6 weeks } & \multicolumn{2}{|l|}{ After 22 weeks } \\
\hline & Coefficient $(95 \% \mathrm{Cl})$ & $\mathrm{p}$ Value & Coefficient $(95 \% \mathrm{Cl})$ & p Value \\
\hline $\begin{array}{l}\text { Baseline sIL2R (per } 100 \mathrm{U} / \mathrm{ml} \text { ) } \\
\text { Baseline DAS28 score } \\
\text { Infliximab dose }(\mathrm{mg} / \mathrm{kg} \text { ) } \\
\text { Constant }\end{array}$ & $\begin{array}{c}0.2054 \text { (0.0035 to } 0.4073) \\
0.0585 \text { (- }-0.5327 \text { to } 0.6498) \\
0.1313(-0.3719 \text { to } 0.6346) \\
-4.995(-8.708 \text { to }-1.2823)\end{array}$ & $\begin{array}{l}0.047 \\
0.84 \\
0.59\end{array}$ & $\begin{array}{r}0.0152(-0.1872 \text { to } 0.2176) \\
-0.3067(-0.8730 \text { to } 0.2595) \\
0.0185(-0.4515 \text { to } 0.4885) \\
-0.1731(-3.220 \text { to } 2.873)\end{array}$ & $\begin{array}{l}0.88 \\
0.27 \\
0.94\end{array}$ \\
\hline
\end{tabular}

CCR3 and CCR5 at baseline compared with non-responders. ${ }^{11}$ The results are in agreement with the present study, indicating that high activation of lymphocytes impairs the efficacy of infliximab treatment. Taken together, these findings raise an intriguing question as to whether the patients with signs of high lymphocyte activation are particularly suitable for treatment with CTLA4Ig ${ }^{12}$ or other drugs suggested to act through inhibition of $\mathrm{T}$ cell activation. $^{13}$

In the present study, the serum sIL2R level did not predict the later (22 week) response. This finding agrees with the previous studies of patients with refractory rheumatoid arthritis treated with methotrexate for 18 weeks, ${ }^{14}$ or DMARD naive patients treated with sulfasalazine or parenteral gold for 37 weeks, ${ }^{15}$ indicating that there is no correlation between initial serum sIL2R level and the response to treatment.

Our patients, being very refractory, had received DMARDs previously and also received them during the whole study period, mostly in combination with prednisolone. A decrease in the sIL2R level may occur during the treatment with methylprednisolone, either as intravenous pulse ${ }^{16}$ or as intramuscular injections, ${ }^{17}$ or during the treatment with some of the DMARDs such as methotrexate ${ }^{14-23}$, ciclosporine $\mathrm{A},{ }^{24}$ and sulfasalazine, ${ }^{15}$ but may not occur during the treatment with parenteral ${ }^{1525}$ or oral $^{26}$ gold, or with azathioprine. ${ }^{192022}$ Thus it is possible that the DMARD treatment may have affected the results by decreasing the sIL2R levels measured before starting infliximab. Furthermore, the DMARDs were continued and may have had synergistic effects with infliximab on the treatment response. Finally, the present study has the common weaknesses of an open label study. To address these questions further, randomised controlled studies with sufficient numbers of patients are needed.

We have shown that in the DMARD-naive patients with early active rheumatoid arthritis participating in the FINRACo study, ${ }^{27}$ low sIL2R level at baseline predicted remission at six months in patients treated with a single DMARD, but not in patients treated with a combination strategy. ${ }^{6}$ With respect to serum sIL2R levels, the patients in the current study-having failed all conventional DMARDs, often used in combinations - were similar to the DMARD-naive patients in the FIN-RACo trial. ${ }^{28}$ Thus a low sIL2R level can be a feature of early rheumatoid arthritis or of established disease and be a marker of a subtype of rheumatoid arthritis, notoriously known to be heterogeneous, and indicate a more rapid and favourable response to treatment.

In conclusion, low circulating sIL2R level, denoting a low degree of lymphocyte activation, may be predictive of a rapid response to treatment with infliximab in patients with refractory rheumatoid arthritis. However, the marker does not identify the patients in remission after 22 weeks. Further studies are needed to clarify the predictive value of sIL2R in infliximab treatment.

\section{ACKNOWLEDGEMENTS}

Supported by grants from Finnish Cultural Foundation, Paulo Foundation, and Helsinki University Central Hospital research funds.

\section{Authors' affiliations}

A Kuuliala, Department of Bacteriology and Immunology, Haartman Institute, University of Helsinki, Helsinki, Finland

R Nissinen, Department of Molecular Medicine, National Public Health Institute, Helsinki

H Kautiainen, Rheumatism Foundation Hospital, Heinola, Finland

H Repo, Division of Infectious Diseases, Department of Medicine, Helsinki University Central Hospital

M Leirisalo-Repo, Division of Rheumatology, Department of Medicine, Helsinki University Central Hospital

\section{REFERENCES}

1 Choy EH, Panayi GS. Cytokine pathways and joint inflammation in rheumatoid arthritis. N Engl J Med 2001;344:907-16.

2 Monaco C, Andreakos E, Kiriakidis S, Feldmann M, Paleolog E. T-cellmediated signalling in immune, inflammatory and angiogenic processes: the cascade of events leading to inflammatory diseases. Curr Drug Targets Inflamm Allergy 2004;3:35-42.

3 Malone DG, Wahl SM, Tsokos M, Cattell H, Decker JL, Wilder RL. Immune function in severe, active rheumatoid arthritis. A relationship between peripheral blood mononuclear cell proliferation to soluble antigens and synovial tissue immunohistologic characteristics. J Clin Invest 1984; $74: 1173-85$

4 Rubin LA, Nelson DL. The soluble interleukin-2 receptor: biology, function, and clinical application. Ann Intern Med 1990;1 13:619-27.

5 Maini RN, Breedveld FC, Kalden JR, Smolen JS, Furst D, Weisman MH, et al. Sustained improvement over two years in physical function, structural damage, and signs and symptoms among patients with rheumatoid arthritis treated with infliximab and methotrexate. Arthritis Rheum 2004;50:1051-65.

6 Kuuliala A, Leirisalo-Repo M, Mottonen T, Hannonen P, Nissila M, Kautiainen $\mathrm{H}$, et al. Predictive value of serum soluble interleukin-2 receptor levels in early rheumatoid arthritis. Arthritis Rheum 2003;48(suppl):S438-9.

7 Hakala M, Nieminen P, Manelius J. Joint impairment is strongly correlated with disability measured by self-report questionnaires. Functional status assessment of individuals with rheumatoid arthritis in a population based series. J Rheumatol 1994;21:64-9.

8 Prevoo ML, 't Hof MA, Kuper HH, van Leeuwen MA, Van de Putte LB, Van Riel PL. Modified disease activity scores that include twenty-eight-joint counts. Development and validation in a prospective longitudinal study of patients with rheumatoid arthritis. Arthritis Rheum 1995;38:44-8.

9 Klimiuk PA, Sierakowski S, Latosiewicz R, Cylwik JP, Cylwik B, Skowronski J, et al. Interleukin-6, soluble interleukin-2 receptor and soluble interleukin-6 receptor in the sera of patients with different histological patterns of rheumatoid synovitis. Clin Exp Rheumatol 2003;21:63-9.

10 Klimiuk PA, Sierakowski S, Latosiewicz R, Cylwik JP, Cylwik B, Skowronski J, et al. Circulating tumour necrosis factor alpha and soluble tumour necrosis factor receptors in patients with different patterns of rheumatoid synovitis. Ann Rheum Dis 2003;62:472-5.

11 Nissinen R, Leirisalo-Repo M, Peltomaa R, Palosuo T, Vaarala O. Cytokine and chemokine receptor profile of peripheral blood mononuclear cells during treatment with infliximab in patients with active rheumatoid arthritis. Ann Rheum Dis 2004;63:681-7.

12 Kremer JM, Westhovens R, Leon M, Di Giorgio E, Alten R, Steinfeld S, et al. Treatment of rheumatoid arthritis by selective inhibition of T-cell activation with fusion protein CTLA4lg. N Engl J Med 2003;349:1907-15.

13 Lorenz HM. T-cell-activation inhibitors in rheumatoid arthritis. BioDrugs 2003; 17:263-70.

14 Polisson RP, Dooley MA, Dawson DV, Pisetsky DS. Interleukin-2 receptor levels in the sera of rheumatoid arthritis patients treated with methotrexate. Arthritis Rheum 1994;37:50-6.

15 Merkel PA, Dooley MA, Dawson DV, Pisetsky DS, Polisson RP. Interleukin-2 receptor levels in sera of patients with rheumatoid arthritis treated with sulfasalazine, parenteral gold, or placebo. J Rheumatol 1996;23:1856-61. 
16 van den Brink HR, van Wiik MJ, Geertzen RG, Bijlsma JW. Influence of corticosteroid pulse therapy on the serum levels of soluble interleukin 2 receptor, interleukin 6 and interleukin 8 in patients with rheumatoid arthritis. J Rheumatol 1994;21:430-4.

17 Kirkham BW, Davison SC, Corkill MM, Barbatis C, Panayi GS. Serial soluble interleukin 2 receptor levels in rheumatoid arthritis: differences in response to glucocorticoid treatment and chrysotherapy. J Rheumatol 1993;20:935-9.

18 Barrera P, Haagsma CJ, Boerbooms AM, Van Riel PL, Borm GF, Van de Putte $L B$, et al. Effect of methotrexate alone or in combination with sulphasalazine on the production and circulating concentrations of cytokines and their antagonists. Longitudinal evaluation in patients with rheumatoid arthritis. Br J Rheumatol 1995;34:747-55.

19 Barrera P, Boerbooms AM, Janssen EM, Sauerwein RW, Gallati H, Mulder J, et al. Circulating soluble tumor necrosis factor receptors, interleukin-2 receptors, tumor necrosis factor alpha, and interleukin- 6 levels in rheumatoid arthritis. Longitudinal evaluation during methotrexate and azathioprine therapy. Arthritis Rheum 1993;36:1070-9.

20 Crilly A, Mclnnes IB, Capell HA, Madhok R. The effect of azathioprine on serum levels of interleukin 6 and soluble interleukin 2 receptor. Scand J Rheumatol 1994;23:87-91

21 Crilly A, Mclnness IB, McDonald AG, Watson J, Capell HA, Madhok R. Interleukin 6 (IL-6) and soluble IL-2 receptor levels in patients with rheumatoid arthritis treated with low dose oral methotrexate. J Rheumatol 1995;22:224-6.

22 Franke S, Herrmann D, Hein G, Muller A, Stein G. Interleukin-6, soluble interleukin-2-receptor and soluble interleukin-6-receptor in sera of patients with rheumatoid arthritis: influences of disease activity and drug therapy Eur J Med Res 1997;2:401-6.

23 Spadaro A, Taccari E, Riccieri V, Sensi F, Sili SA, Zoppini A. Relationship of soluble interleukin-2-receptor and interleukin-6 with class-specific rheumatoid factors during low-dose methotrexate treatment in rheumatoid arthritis. Rev Rhum Engl Ed 1997;64:89-94.

24 Crilly A, Kolta S, Dougados M, Sturrock RD, Amor B, Capell HA, et al. Effect of cyclosporin $A$ on interleukin- 6 and soluble interleukin-2 receptor in patients with rheumatoid arthritis. Ann Rheum Dis 1995;54:137-9.

25 Sheldon A, Ahern MJ, Smith MD, Zola H, Roberts-Thomson PJ. Response of soluble IL-2 receptor levels during gold therapy for rheumatoid arthritis. Clin Exp Rheumatol 1994;12:175-8.

26 Boiardi L, Macchioni P, Salvarani C, Rossi F, Casadei-Maldini M, Mancini R, et al. Serum soluble interleukin-2 receptor levels in rheumatoid arthritis: correlation with clinical and immunological parameters and w ith the response to auranofin treatment. Clin Exp Rheumatol 1994; 12:357-62.

27 Mottonen T, Hannonen P, Leirisalo-Repo M, Nissila M, Kautiainen $\mathrm{H}$, Korpela $M$, et al. Comparison of combination therapy with single-drug therapy in early rheumatoid arthritis: a randomised trial. FIN-RACo trial group. Lancet 1999;353:1568-73.

28 Mottonen T, Hannonen P, Korpela M, Nissila M, Kautiainen H, llonen J, et al. Delay to institution of therapy and induction of remission using single-drug or combination-disease-modifying antirheumatic drug therapy in early rheumatoid arthritis. Arthritis Rheum 2002;46:894-8.

11 th European Forum on Quality Improvement in Health Care

26-28 April 2006, Prague, Czech Republic For further information please go to: www.quality.bmipg.com Book early to benefit from a discounted delegate rate 